\title{
Effect on the structure and morphology of vanadium phosphates of the addition of alkanes during the alcohol reduction of $\mathrm{VOPO}_{4} \cdot 2 \mathrm{H}_{2} \mathrm{O} \dagger$
}

\author{
Umacaran Sithamparappillai, ${ }^{a}$ Jesús Luque Nuño, ${ }^{b}$ Nicholas F. Dummer, ${ }^{a}$ Weihao Weng, ${ }^{c}$ Christopher J. Kiely, \\ Jonathan K. Bartley ${ }^{a}$ and Graham J. Hutchings $* a$
}

\author{
Received 12th February 2010, Accepted 21st April 2010 \\ First published as an Advance Article on the web 17th May 2010 \\ DOI: 10.1039/c0jm00403k
}

\begin{abstract}
Vanadium phosphate catalysts were prepared by the reduction of $\mathrm{VOPO}_{4} \cdot 2 \mathrm{H}_{2} \mathrm{O}$ with an alcohol and characterised using a combination of powder XRD, BET surface area measurement, scanning electron microscopy and transmission electron microscopy. The effect of the addition of an alkane co-solvent during the reflux stage of the preparation was investigated. The addition of $\mathrm{C}_{4}-\mathrm{C}_{16} n$-alkanes was observed to affect the structure of the vanadium phosphate products significantly. Without the alkane the product is $\mathrm{VOHPO}_{4} \cdot 0.5 \mathrm{H}_{2} \mathrm{O}$ which is the precursor to the industrial catalyst. Addition of the alkane leads to the formation of $\mathrm{VO}\left(\mathrm{H}_{2} \mathrm{PO}_{4}\right)_{2}$, with its characteristic block-shaped crystallites, and the alkane/alcohol liquid phase solubilises the excess vanadium. The amount of alkane required to induce these changes decreased with increasing carbon number of the $n$-alkane. The effect of the addition of the alkane co-solvent is thought to effect the rate of reduction of $\mathrm{V}^{5+}$ to $\mathrm{V}^{4+}$ which then reacts with phosphoric acid to give either $\mathrm{VOHPO}_{4} \cdot 0.5 \mathrm{H}_{2} \mathrm{O}$ or $\mathrm{VO}\left(\mathrm{H}_{2} \mathrm{PO}_{4}\right)_{2}$. If the reduction step is fast then the local $\mathrm{P}: \mathrm{V}^{4+}$ ratio is approximately 1 and $\mathrm{VOHPO}_{4} \cdot 0.5 \mathrm{H}_{2} \mathrm{O}$ is the major product. However, if the reduction step is slow then the local $\mathrm{P}: \mathrm{V}^{4+}$ ratio is much higher and $\mathrm{VO}\left(\mathrm{H}_{2} \mathrm{PO}_{4}\right)_{2}$ is preferentially formed.
\end{abstract}

\section{Introduction}

The selective oxidation of $n$-butane to maleic anhydride using vanadium phosphate catalysts has been extensively studied in recent years. The catalytic performance of vanadium phosphates depends on the method of preparation of the catalyst precursor $^{1-14}$ and the reaction conditions used for the in situ activation in $n$-butane/air to form the final catalyst. ${ }^{4,5}$ The transformation of the precursor to the final catalyst is topotactic and the morphology of the precursor is of crucial importance in determining the eventual catalyst morphology and the performance following activation.

Many well characterised, crystalline vanadium phosphate phases have been identified whose structure and catalytic properties have been well documented. Some of the most widely studied are the $\mathrm{V}^{5+}$ vanadyl orthophosphates $(\alpha-, \beta-, \gamma-, \delta-, \varepsilon-$ and $\omega-\mathrm{VOPO}_{4}, \mathrm{VOPO}_{4} \cdot \mathrm{H}_{2} \mathrm{O}$ and $\left.\mathrm{VOPO}_{4} \cdot 2 \mathrm{H}_{2} \mathrm{O}\right)$, and the $\mathrm{V}^{4+}$ vanadyl hydrogen phosphates $\left(\mathrm{VOHPO}_{4} \cdot 4 \mathrm{H}_{2} \mathrm{O}\right.$, VOH$\mathrm{PO}_{4} \cdot 0.5 \mathrm{H}_{2} \mathrm{O}$, $\left.\mathrm{VO}\left(\mathrm{H}_{2} \mathrm{PO}_{4}\right)_{2}\right)$, vanadyl pyrophosphate $\left((\mathrm{VO})_{2} \mathrm{P}_{2} \mathrm{O}_{7}\right)$ and vanadyl metaphosphate $\left(\mathrm{VO}\left(\mathrm{PO}_{3}\right)_{2}\right)$. Despite the number of phases that have been reported, standard preparation methods, in which a vanadium source is reacted with

${ }^{a}$ School of Chemistry, Cardiff University, Cardiff, CF10 3AT, UK. E-mail: hutch@cf.ac.uk

${ }^{b}$ Department of Chemistry, Universidad de Córdoba, 14014 Córdoba, Spain 'Department of Materials Science and Engineering, Lehigh University, 5 East Packer Avenue, Bethlehem, PA, 18015-3195, USA

$\dagger$ Electronic supplementary information (ESI) available: Detailed XRD patterns and peak assignments for the materials shown in Fig. 1, 3, 6 and 7, and further characterisation of the samples prepared with 1-butanol and different chain length $n$-alkanes. See DOI: $10.1039 / \mathrm{c} 0 \mathrm{jm} 00403 \mathrm{k}$ phosphoric acid in the presence of a reducing agent, tend to form either $\mathrm{VOHPO}_{4} \cdot 0.5 \mathrm{H}_{2} \mathrm{O}$ or $\mathrm{VO}\left(\mathrm{H}_{2} \mathrm{PO}_{4}\right)_{2}$, or more usually a mixture of the two materials. It is widely accepted that the best catalysts are based on $\mathrm{VOHPO}_{4} \cdot 0.5 \mathrm{H}_{2} \mathrm{O}$ precursors which on activation form a catalyst mainly comprising $(\mathrm{VO})_{2} \mathrm{P}_{2} \mathrm{O}_{7}$. However, $\mathrm{VO}\left(\mathrm{H}_{2} \mathrm{PO}_{4}\right)_{2}$ when activated forms $\mathrm{VO}\left(\mathrm{PO}_{3}\right)_{2}$ which has been shown to have very poor selectivity for maleic anhydride. ${ }^{15,16}$ Consequently preparations of $\mathrm{VOHPO}_{4} \cdot 0.5 \mathrm{H}_{2} \mathrm{O}$ often require removal of the unwanted $\mathrm{VO}\left(\mathrm{H}_{2} \mathrm{PO}_{4}\right)_{2}$ by solvent extraction. ${ }^{16,17}$

The initial preparations of $\mathrm{VOHPO}_{4} \cdot 0.5 \mathrm{H}_{2} \mathrm{O}$ were carried out under reflux in water with $\mathrm{HCl}$ as the reducing agent, ${ }^{14,18-20}$ although oxalic acid, ${ }^{20}$ lactic acid, ${ }^{21}$ phosphorous acid, ${ }^{21,22}$ and $\mathrm{NH}_{2} \mathrm{OH} \cdot \mathrm{HCl}^{23}$ have all been investigated as reducing agents in place of hydrochloric acid. More recently the preparation of $\mathrm{VOHPO}_{4} \cdot 0.5 \mathrm{H}_{2} \mathrm{O}$ has been carried out via a two-step procedure. ${ }^{1-3} \mathrm{VOPO}_{4} \cdot 2 \mathrm{H}_{2} \mathrm{O}$ is prepared by heating an aqueous solution of $\mathrm{V}_{2} \mathrm{O}_{5}$ and $\mathrm{H}_{3} \mathrm{PO}_{4}$ under reflux. The $\mathrm{VOPO}_{4} \cdot 2 \mathrm{H}_{2} \mathrm{O}$ is then reduced, usually in an alcohol, to give the $\mathrm{VOHPO}_{4} \cdot 0.5 \mathrm{H}_{2} \mathrm{O}$ precursor. There have also been investigations into alternative vanadium sources with $\mathrm{V}_{4} \mathrm{O}_{9},{ }^{24,25} \mathrm{NH}_{4} \mathrm{VO}_{3},{ }^{20} \mathrm{VCl}_{3} / \mathrm{V}_{2} \mathrm{O}_{5}{ }^{26}$ and $\mathrm{V} / \mathrm{V}_{2} \mathrm{O}_{5}{ }^{27}$ mixtures being used as well as the direct reaction of $\mathrm{V}_{2} \mathrm{O}_{4}$ and $\mathrm{H}_{3} \mathrm{PO}_{4}{ }^{23}$

When the reaction between $\mathrm{V}_{2} \mathrm{O}_{5}, \mathrm{H}_{3} \mathrm{PO}_{4}$ and a reducing agent is carried out in excess phosphoric acid $\mathrm{VO}\left(\mathrm{H}_{2} \mathrm{PO}_{4}\right)_{2}$ is found to be the major product. ${ }^{22,26}$ This is perhaps unsurprising as a high $\mathrm{P}: \mathrm{V}$ ratio in the starting material favours a product with a $\mathrm{P}: \mathrm{V}$ ratio of 2 . What is perhaps more surprising is the fact that $\mathrm{VOPO}_{4} \cdot 2 \mathrm{H}_{2} \mathrm{O}$ with a fixed $\mathrm{P}$ : V ratio of 1 can be reduced with either 3 -octanol ${ }^{3}$ or an aldehyde or ketone ${ }^{15}$ to give $\mathrm{VO}\left(\mathrm{H}_{2} \mathrm{PO}_{4}\right)_{2}$. 
In view of the importance of the catalyst precursor, there have been numerous studies concerned with catalyst preparation. However, the factors that influence the formation of either $\mathrm{VOHPO}_{4} \cdot 0.5 \mathrm{H}_{2} \mathrm{O}$ or $\mathrm{VO}\left(\mathrm{H}_{2} \mathrm{PO}_{4}\right)_{2}$ are not well understood. In this study the addition of an alkane co-solvent has been studied, a variable which has not been considered in detail in any previous scientific publications and patents. Using an inert co-solvent it was found that the product of the preparation can be either $\mathrm{VOHPO}_{4} \cdot 0.5 \mathrm{H}_{2} \mathrm{O}$ or $\mathrm{VO}\left(\mathrm{H}_{2} \mathrm{PO}_{4}\right)_{2}$ depending on the reaction conditions. This enables a possible mechanism for the formation of these two materials to be suggested.

\section{Experimental}

Vanadium phosphate dihydrate $\left(\mathrm{VOPO}_{4} \cdot 2 \mathrm{H}_{2} \mathrm{O}\right)$ was prepared by the standard method described by Johnson et al. ${ }^{1} \mathrm{~V}_{2} \mathrm{O}_{5}(10.0 \mathrm{~g}$, Aldrich) and $\mathrm{H}_{3} \mathrm{PO}_{4}(60 \mathrm{ml}$, Aldrich) were refluxed in water $(120 \mathrm{ml})$ under reflux conditions for $24 \mathrm{~h}$. The yellow solid was recovered by vacuum filtration, washed with cold water $(100 \mathrm{ml})$ and acetone $(100 \mathrm{ml})$ and dried in air for $24 \mathrm{~h}$.

The $\mathrm{VOPO}_{4} \cdot 2 \mathrm{H}_{2} \mathrm{O}$ was then reduced with alcohol (1-butanol or 1-octanol) in the presence of an alkane co-solvent $\left(\mathrm{C}_{4}-\mathrm{C}_{16}\right)$. The synthesis was carried out using two methodologies. The first procedure fixed the amount of $\mathrm{VOPO}_{4} \cdot 2 \mathrm{H}_{2} \mathrm{O}$ and the total volume whilst varying the alcohol/alkane ratio. $\mathrm{VOPO}_{4} \cdot 2 \mathrm{H}_{2} \mathrm{O}$ $(1.0 \mathrm{~g})$ was refluxed for $24 \mathrm{~h}$ in a solvent mixture containing 0,5 , $15,25,50,100,125,150,160,170$ and $175 \mathrm{ml}$ of alcohol and made up to a total volume of $175 \mathrm{ml}$ with alkane (Table 1). In the second procedure the solvent compositions above were used but the amount of $\mathrm{VOPO}_{4} \cdot 2 \mathrm{H}_{2} \mathrm{O}$ was varied to keep a $\mathrm{V}$ : alcohol molar ratio of $1: 50$ (Table 2 ). The resulting solids were recovered by vacuum filtration and washed with alcohol $(50 \mathrm{ml})$ and acetone $(50 \mathrm{ml})$ and dried in air at $110^{\circ} \mathrm{C}$ for $24 \mathrm{~h}$.

The materials were characterised using a combination of powder X-ray diffraction, BET surface area measurements, scanning electron microscopy (SEM) and transmission electron microscopy (TEM). Powder X-ray diffraction (XRD) was performed using an Enraf Nonius FRS 590 X-ray generator with a $\mathrm{CuK} \alpha$ source fitted with an Inel CPS 120 hemispherical detector. BET surface area measurements using nitrogen adsorption were carried out using a Micromeritics ASAP 2010 instrument. SEM was performed on a Hitachi 326YO-N

Table 1 Materials prepared by reacting $1.0 \mathrm{~g}$ of $\mathrm{VOPO}_{4} \cdot 2 \mathrm{H}_{2} \mathrm{O}$ with different amounts of 1-octanol and octane

\begin{tabular}{lllcl}
\hline Material & VOPO $_{4} \cdot 2 \mathrm{H}_{2} \mathrm{O} / \mathrm{g}$ & $\mathrm{V}: \mathrm{ROH}^{a}$ & $1-$ Octanol $/ \mathrm{ml}$ & Octane $/ \mathrm{ml}$ \\
\hline O1-0 & 1.0 & - & 0 & 175 \\
O1-15 & 1.0 & $1: 15$ & 15 & 160 \\
O1-40 & 1.0 & $1: 40$ & 40 & 135 \\
O1-50 & 1.0 & $1: 50$ & 50 & 125 \\
O1-75 & 1.0 & $1: 75$ & 75 & 100 \\
O1-100 & 1.0 & $1: 100$ & 100 & 75 \\
O1-125 & 1.0 & $1: 125$ & 125 & 50 \\
O1-135 & 1.0 & $1: 135$ & 135 & 40 \\
O1-150 & 1.0 & $1: 150$ & 150 & 25 \\
O1-160 & 1.0 & $1: 160$ & 160 & 15 \\
O1-175 & 1.0 & $1: 175$ & 175 & 0
\end{tabular}

${ }^{a}$ Vanadium to alcohol molar ratio.
Table 2 Materials prepared by reacting $\mathrm{VOPO}_{4} \cdot 2 \mathrm{H}_{2} \mathrm{O}$ with different amounts of 1-octanol and octane keeping the $\mathrm{V}: \mathrm{ROH}$ mole ratio of $1: 50$

\begin{tabular}{lllcc}
\hline Material & VOPO $_{4} \cdot 2 \mathrm{H}_{2} \mathrm{O} / \mathrm{g}$ & $\mathrm{V}: \mathrm{ROH}^{a}$ & $1-\mathrm{Octanol} / \mathrm{ml}$ & Octane $/ \mathrm{ml}$ \\
\hline $\mathrm{O} 2-15$ & 0.3 & $1: 50$ & 15 & 160 \\
$\mathrm{O} 2-40$ & 0.8 & $1: 50$ & 40 & 135 \\
$\mathrm{O} 2-50$ & 1.0 & $1: 50$ & 50 & 125 \\
$\mathrm{O} 2-75$ & 1.5 & $1: 50$ & 75 & 100 \\
$\mathrm{O} 2-100$ & 2.0 & $1: 50$ & 100 & 75 \\
$\mathrm{O} 2-115$ & 2.3 & $1: 50$ & 115 & 60 \\
$\mathrm{O} 2-125$ & 2.5 & $1: 50$ & 125 & 50 \\
$\mathrm{O} 2-135$ & 2.75 & $1: 50$ & 135 & 40 \\
$\mathrm{O} 2-160$ & 3.2 & $1: 50$ & 160 & 15 \\
$\mathrm{O} 2-175$ & 3.5 & $1: 50$ & 175 & 0
\end{tabular}

${ }^{a}$ Vanadium to alcohol molar ratio.

instrument operating at $20 \mathrm{kV}$. TEM imaging and electron diffraction analysis were carried out on a JEOL 2000FX microscope operating at $200 \mathrm{kV}$. Samples were prepared for TEM examination by dispersing the VPO powder in ethanol, and then allowing a drop of the resulting suspension to dry on a holey carbon film supported on a $\mathrm{Cu}$ mesh grid.

\section{Results and discussion}

A number of reductions of $\mathrm{VOPO}_{4} \cdot 2 \mathrm{H}_{2} \mathrm{O}$ were carried out using different alcohol/alkane solvent mixtures. By using $\mathrm{VOPO}_{4} \cdot 2 \mathrm{H}_{2} \mathrm{O}$ as the starting material, and using an alkane as a co-solvent, we can minimize the different processes that can occur during the synthesis. Using this methodology we can fix the $\mathrm{P}: \mathrm{V}$ ratio of the reactants at $1: 1$ which means that any differences observed are not due to fluctuations in the $\mathrm{P}: \mathrm{V}$ ratio, reactions of by-products, or reactions with the alkane solvent.

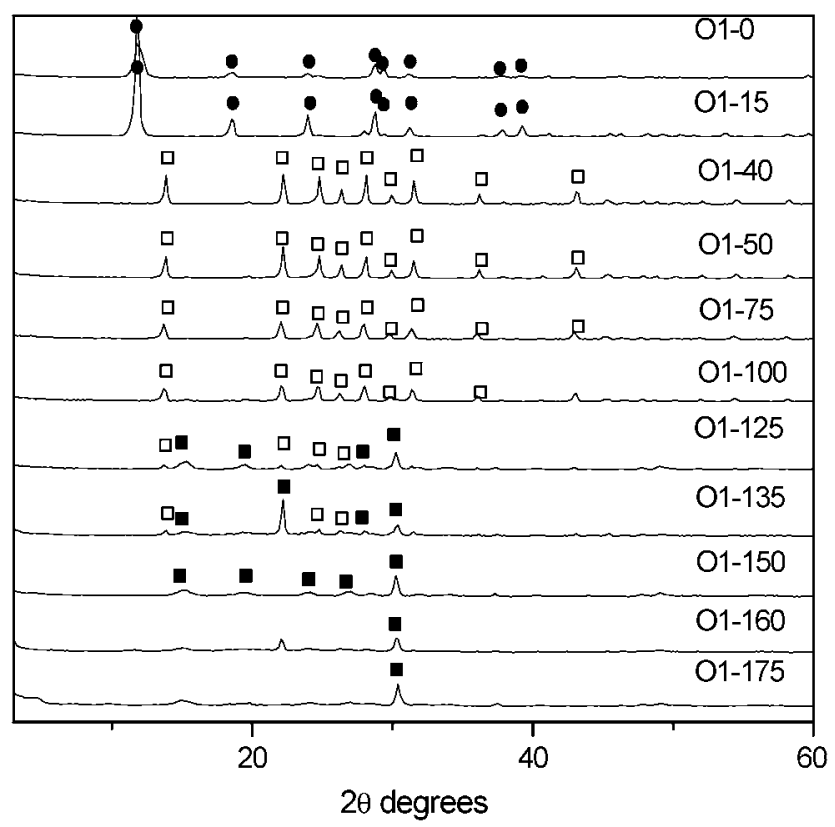

Fig. 1 The XRD patterns of the materials prepared by reacting $1.0 \mathrm{~g}$ of $\mathrm{VOPO}_{4} \cdot 2 \mathrm{H}_{2} \mathrm{O}$ with different amounts of 1-octanol and octane. Key: $=\mathrm{VOHPO}_{4} \cdot 0.5 \mathrm{H}_{2} \mathrm{O} ; \square=\mathrm{VO}\left(\mathrm{H}_{2} \mathrm{PO}_{4}\right)_{2} ; \boldsymbol{\bullet}=\mathrm{VOPO}_{4} \cdot 2 \mathrm{H}_{2} \mathrm{O}$. 
Therefore, the origin of any differences observed is thought to be physical in nature rather than a chemical effect.

Initial experiments were performed using 1-octanol as the reducing agent and octane as the co-solvent. A summary of the preparations carried out is shown in Table 1. When octane is used as the sole solvent in the absence of alcohol no reaction is observed (Fig. 1, O1-0). This is consistent with the alkane being an inert co-solvent which does not directly take part in the reaction. As the mole fraction of 1-octanol in the solvent mixture is increased, while keeping the number of moles of vanadium the same, the $\mathrm{VOPO}_{4} \cdot 2 \mathrm{H}_{2} \mathrm{O}$ has been shown to reduce when the solvent mixture is $40 \mathrm{ml}$ of 1-octanol/135 ml of octane (Fig. 1, O1-40). However, the product identified in the XRD pattern is
$\mathrm{VO}\left(\mathrm{H}_{2} \mathrm{PO}_{4}\right)_{2}$ not $\mathrm{VOHPO}_{4} \cdot 0.5 \mathrm{H}_{2} \mathrm{O}$ as would be expected without the co-solvent (Fig. 1, O1-175). It is not until a solvent mixture of $125 \mathrm{ml}$ of 1 -octanol/50 $\mathrm{ml}$ octane is used that $\mathrm{VOH}-$ $\mathrm{PO}_{4} \cdot 0.5 \mathrm{H}_{2} \mathrm{O}$ is observed in the XRD pattern (Fig. 1, O1-125)initially in a mixture with $\mathrm{VO}\left(\mathrm{H}_{2} \mathrm{PO}_{4}\right)_{2}$, and finally as the sole product when the solvent mixture is $150 \mathrm{ml}$ of 1 -octanol $/ 25 \mathrm{ml}$ octane (Fig. 1, O1-150).

The trend observed in the XRD patterns (Fig. 1, see ESI $\dagger$, Fig. S1 for detailed XRD patterns and phase assignments) is confirmed by the SEM images (Fig. 2). At low amounts of 1octanol (Fig. 2, O1-0, O1-15) the morphology consists of large circular or octagonal plates which is reminiscent of the $\mathrm{VOPO}_{4} \cdot 2 \mathrm{H}_{2} \mathrm{O}$ starting material. As the amount of alcohol is
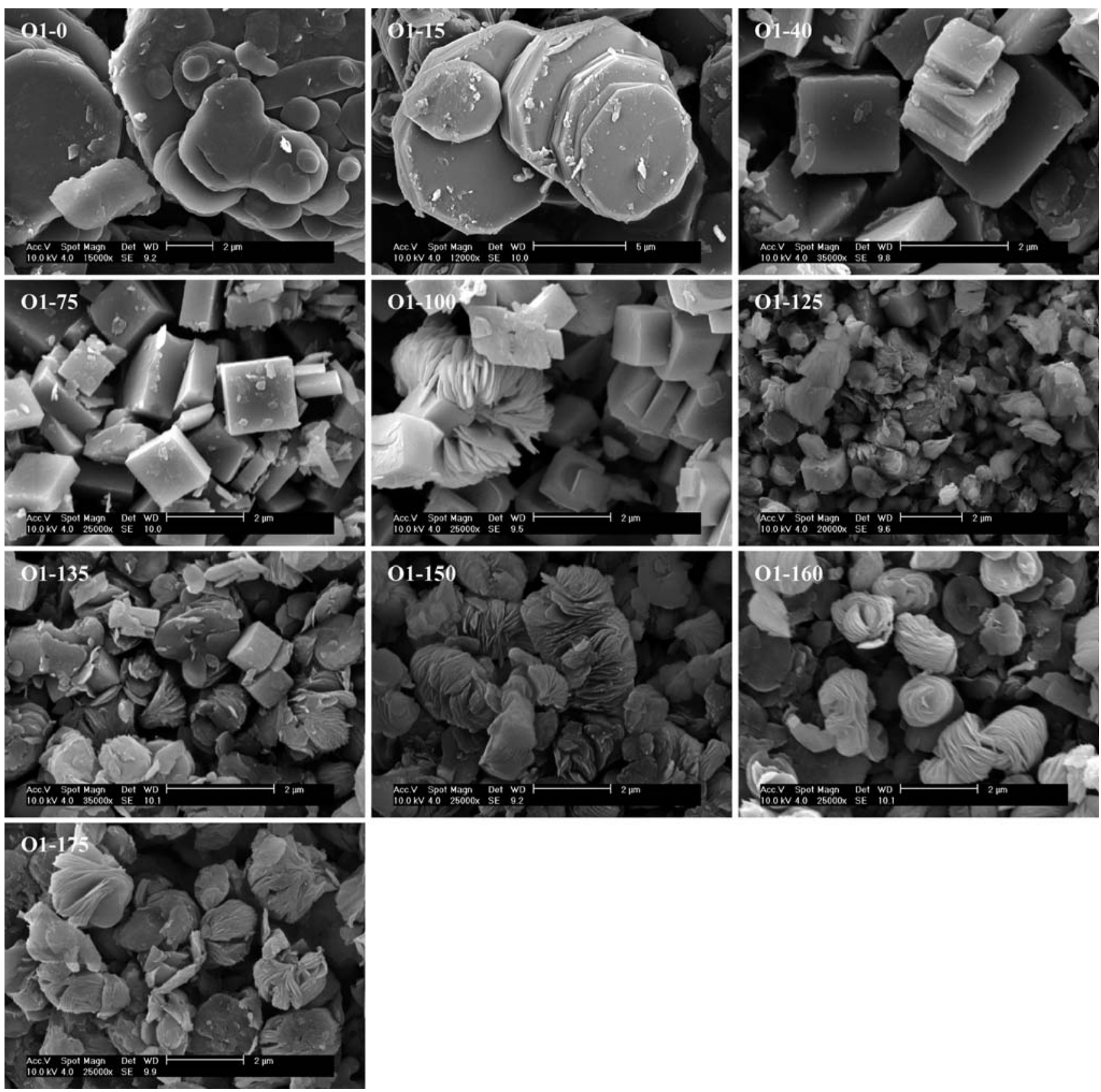

Fig. $2 \mathrm{SEM}$ micrographs of the materials prepared by reacting $1.0 \mathrm{~g}$ of $\mathrm{VOPO}_{4} \cdot 2 \mathrm{H}_{2} \mathrm{O}$ with different amounts of 1-octanol and octane. 
increased the dominant morphology is small cubes which is characteristic of $\mathrm{VO}\left(\mathrm{H}_{2} \mathrm{PO}_{4}\right)_{2}$ (Fig. 2, O1-40, O1-75, O1-100) until the solvent mixture contains $135 \mathrm{ml} 1$-octanol and rosette structures characteristic of $\mathrm{VOHPO}_{4} \cdot 0.5 \mathrm{H}_{2} \mathrm{O}$ appear in the micrographs (Fig. 2, O1-125, O1-135, O1-150, O1-175).

By using the experimental methodology described above both the mole fraction of 1-octanol in the solvent mixture and the $\mathrm{V}$ : alcohol ratio are changing with changes in the solvent composition (Table 1). To try and determine which of these parameters is important in determining the product a second set of experiments were carried out using the same solvent mixtures but varying the amount of $\mathrm{VOPO}_{4} \cdot 2 \mathrm{H}_{2} \mathrm{O}$ to maintain an $\mathrm{V}$ : alcohol ratio of $1: 50$. The reaction mixtures used are shown in Table 2 .

The XRD patterns of the materials prepared by varying the solvent composition whilst maintaining the $\mathrm{V}$ : alcohol ratio are shown in Fig. 3 with detailed XRD patterns shown in Fig. S2, ESI $\dagger$. It can be seen that the trend is similar to when different solvent mixtures were used with a fixed amount of $\mathrm{VOPO}_{4} \cdot 2 \mathrm{H}_{2} \mathrm{O}$. At low concentrations of 1-octanol (Fig. 3, O2$15)$ there is no reduction-although there is a splitting of the (001) and (002) reflections. This could be due to the intercalation of the alcohol into the layered structure of $\mathrm{VOPO}_{4} \cdot 2 \mathrm{H}_{2} \mathrm{O}$ to form $\mathrm{VOPO}_{4} \cdot n \mathrm{ROH}$ which has a slightly different $d$ spacing in this direction. ${ }^{29,30}$

As the 1-octanol content is increased there is a change in the XRD pattern indicating that $\mathrm{VO}\left(\mathrm{H}_{2} \mathrm{PO}_{4}\right)_{2}$ is again formed at intermediate alcohol concentration (Fig. 3, O2-40, O2-50), and $\mathrm{VOHPO}_{4} \cdot 0.5 \mathrm{H}_{2} \mathrm{O}$ is formed at high alcohol concentration (Fig. 3, O2-75, O2-100, O2-115, O2-125, O2-135, O2-160, O2175).

Using the constant $\mathrm{V}$ : alcohol ratio methodology differences can be observed when compared to the variable $\mathrm{V}$ : alcohol methodology. The transition from $\mathrm{VO}\left(\mathrm{H}_{2} \mathrm{PO}_{4}\right)_{2}$ to

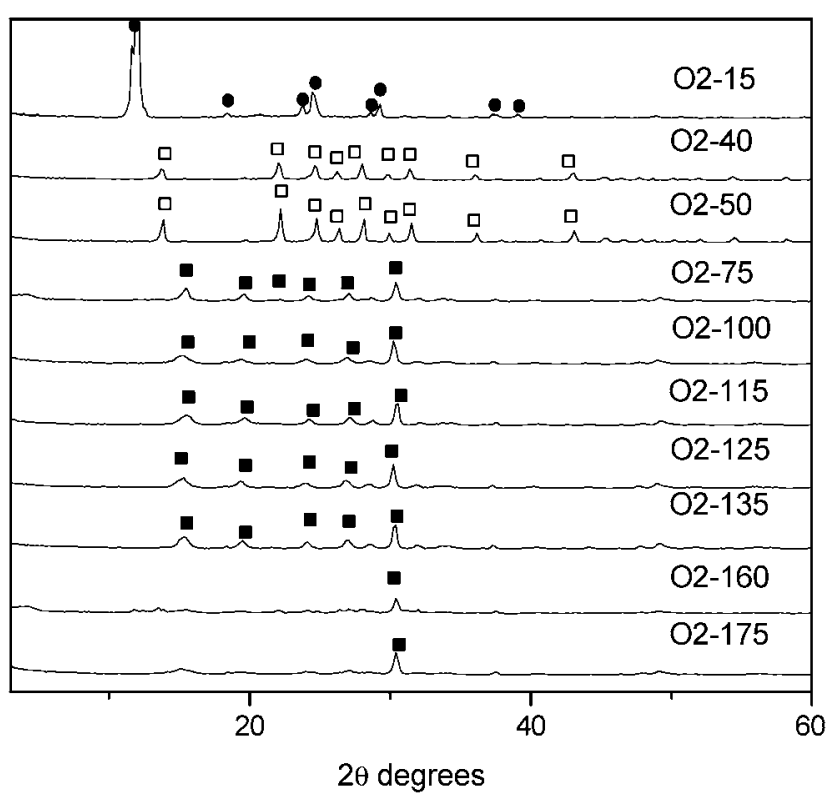

Fig. 3 The XRD patterns of the materials prepared using different amounts of 1-octanol and octane as solvent with a $\mathrm{V}: \mathrm{ROH}$ ratio of 1 : 50. Key: $\square=\operatorname{VOHPO}_{4} \cdot 0.5 \mathrm{H}_{2} \mathrm{O} ; \square=\mathrm{VO}\left(\mathrm{H}_{2} \mathrm{PO}_{4}\right)_{2} ; \boldsymbol{\square}=$ $\mathrm{VOPO}_{4} \cdot 2 \mathrm{H}_{2} \mathrm{O}$.
VOHPO $_{4} \cdot 0.5 \mathrm{H}_{2} \mathrm{O}$ occurs when there is a lower amount of 1 octanol in the solvent mixture and there is no solvent mixture that gives an XRD pattern with both phases present. The SEM images (Fig. 4) confirm the XRD data with large flat plates of $\mathrm{VOPO}_{4} \cdot 2 \mathrm{H}_{2} \mathrm{O}$ (Fig. 4, O2-15) progressing to blocky, cubic $\mathrm{VO}\left(\mathrm{H}_{2} \mathrm{PO}_{4}\right)_{2}$ (Fig. 4, O2-40, O2-50) as the amount of 1-octanol in the reaction mixture is increased. It can also be observed that as the mole fraction of alcohol in the solvent increases there is a shift in the morphology of the $\mathrm{VOHPO}_{4} \cdot 0.5 \mathrm{H}_{2} \mathrm{O}$ from platelets (Fig. 4, O2-75, O2-100, O2-115) to rosettes (Fig. 4, O2-125, O2135, O2-160, O2-175). This shift in morphology can also be observed in the XRD patterns with the platelet morphology having an intense (001) reflection and rosettes characteristically having the (220) reflection as the dominant feature. ${ }^{3,31}$ From these experiments it seems clear that the major influence on which phase is formed is the composition of the reduction solution rather than the $\mathrm{V}$ : alcohol ratio.

Detailed TEM studies were performed on the various crystallite morphologies noted in Fig. 2 and 4 in order to carry out phase identification, measure crystallite dimensions, and characterize facet termination planes. Representative bright field micrographs and selected area diffraction patterns obtained in this study are presented in Fig. 5.

The starting dihydrate material (e.g. O1-15) consisted of octagonal platelets (Fig. 5(a)) that were typically $5 \mu \mathrm{m}$ in diameter and $0.2-1.0 \mu \mathrm{m}$ in thickness. Selected area diffraction patterns (SADPs) obtained from the platelet normal direction (Fig. 5(b)) could be indexed to the [001] projection of the tetragonal $\mathrm{VOPO}_{4} \cdot 2 \mathrm{H}_{2} \mathrm{O}$ phase (Fig. 5(c)). The edge facets of the octagon, each with a $45^{\circ}$ intersection angle, correspond to alternating $\{100\}$ and $\{110\}$-type planes around the [001] axis. Characteristic square or rectangular block-type crystal morphologies (Fig. 5(d)) were produced when using high amounts of octane as a co-solvent ( $c f$. O1-40 to O1-100; O2-40 to $\mathrm{O} 2-50$ ). The SADP from such a particle (Fig. 5(e)) matched the [001] projection of tetragonal $\mathrm{VO}\left(\mathrm{H}_{2} \mathrm{PO}_{4}\right)_{2}$ (Fig. 5(f)). These crystallites were typically about $1 \mu \mathrm{m} \times 1 \mu \mathrm{m} \times 2 \mu \mathrm{m}$ in dimension and presented (001), (010) and (100) facet termination planes.

In the intermediate octane solvent range (i.e. $\mathrm{O} 1-100, \mathrm{O} 2-100$ to O2-135) distinctive angular platelet crystals which had a tendency to stack together were noted (Fig. 5(g)). The lateral dimensions of the major and minor axes of these platelets were typically $2 \mu \mathrm{m} \times 1 \mu \mathrm{m}$ and their thicknesses were in the $0.03-0.2$ $\mu \mathrm{m}$ range. SADPs (Fig. 5(h)) from the platelet normal direction corresponded to the [001] projection of orthorhombic $\mathrm{VOH}-$ $\mathrm{PO}_{4} \cdot 0.5 \mathrm{H}_{2} \mathrm{O}$ (Fig. 5(i)). The edge facet termination planes of these angular platelets were $\{140\}$ and $\{1 \overline{4} 0\}$-type.

Characteristic rosette type structures were observed (Fig. 5(j)) in samples with a low amount of octane as a co-solvent (e.g. O1150 to $\mathrm{O} 1-175$ : O2-160 to $\mathrm{O} 2-175$ ). The rosettes were typically about $2 \mu \mathrm{m}$ in diameter and consisted of a complex radial stack of platelets that were $0.03-0.2 \mu \mathrm{m}$ in thickness. Occasionally some of these platelets would break off allowing us to collect SADPs from individual 'petals' of the rosette (Fig. 5(k) and (1)). Analysis of such SADPs allowed us to confirm that they were $\mathrm{VOHPO}_{4} \cdot 0.5 \mathrm{H}_{2} \mathrm{O}$ and exhibited [001] platelet normals.

Samples displaying XRD patterns that were superpositions of $\mathrm{VO}\left(\mathrm{H}_{2} \mathrm{PO}_{4}\right)_{2}$ and $\mathrm{VOHPO}_{4} \cdot 0.5 \mathrm{H}_{2} \mathrm{O}$ peaks (e.g. $\mathrm{O} 1-125$ and 

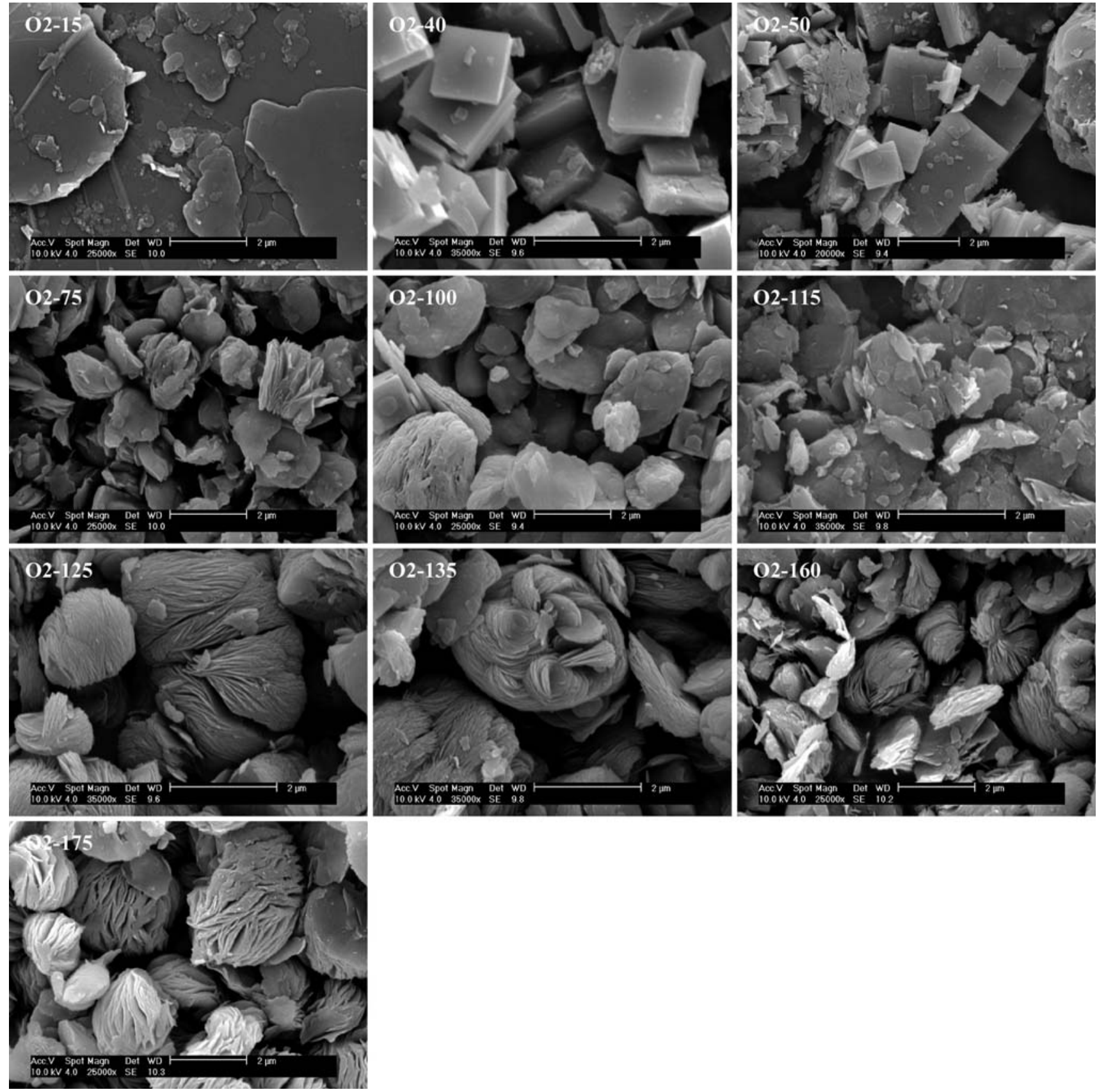

Fig. 4 SEM micrographs of the materials prepared using different amounts of 1-octanol and octane as solvent with a V : ROH ratio of $1: 50$.

O1-135) showed both angular platelets and blocky morphologies (Fig. 5(m)). Selected area electron diffraction analysis (Fig. 5(n) and (o)) of each of these structures allowed us to directly confirm that these corresponded to $\mathrm{VOHPO}_{4} \cdot 0.5 \mathrm{H}_{2} \mathrm{O}$ and $\mathrm{VO}\left(\mathrm{H}_{2} \mathrm{PO}_{4}\right)_{2}$.

When these co-solvent preparation experiments were carried out with 1-butanol instead of 1-octanol (Tables 3 and 4) a similar trend in structural modification was observed in both the XRD (Fig. 6 and 7, see ESI $\dagger$, Fig. S3 and S4 for more detailed patterns and phase assignments) and SEM (ESI†, Fig. S5 and S6), but the conditions under which $\mathrm{VO}\left(\mathrm{H}_{2} \mathrm{PO}_{4}\right)_{2}$ could be formed were much more narrow range of concentrations. When the constant $\mathrm{V}$ : alcohol ratio methodology was used $\mathrm{VO}\left(\mathrm{H}_{2} \mathrm{PO}_{4}\right)_{2}$ could be observed as a mixture with $\mathrm{VOHPO}_{4} \cdot 0.5 \mathrm{H}_{2} \mathrm{O}$ at a solvent composition of $15 \mathrm{ml}$ butanol/160 ml octane (Fig. 6, B2-15). At higher concentrations the product observed was exclusively $\mathrm{VOHPO}_{4} \cdot 0.5 \mathrm{H}_{2} \mathrm{O}$ (Fig. 6, B2-25, B2-50, B2-75) and at very high concentrations $\mathrm{VOHPO}_{4} \cdot 1.5 \mathrm{H}_{2} \mathrm{O}$ is observed as an additional product (ESI $\dagger$, Fig. S3). When the variable $\mathrm{V}$ : alcohol ratio methodology was used $\mathrm{VOHPO}_{4} \cdot 0.5 \mathrm{H}_{2} \mathrm{O}$ was the only product observed, even when the solvent mixture was $5 \mathrm{ml}$ butanol/170 ml octane (Fig. 7, ESI†, Fig. S4). It should be noted that when the experiments are carried out in 1-butanol there is a different molar ratio of $\mathrm{V}:$ alcohol for a given solvent mixture than when 1-octanol is used. However, from the results it appear 

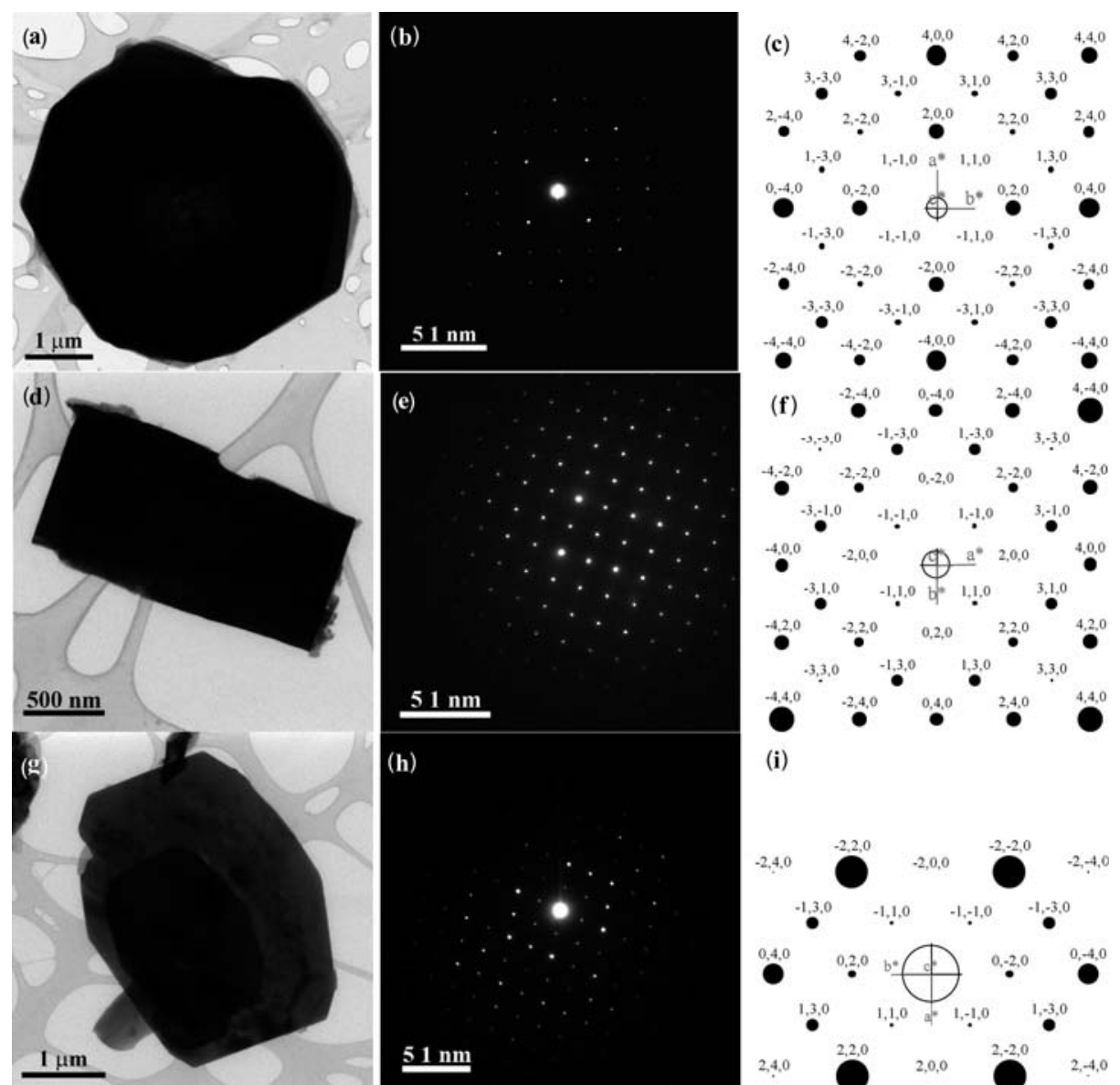

(e)
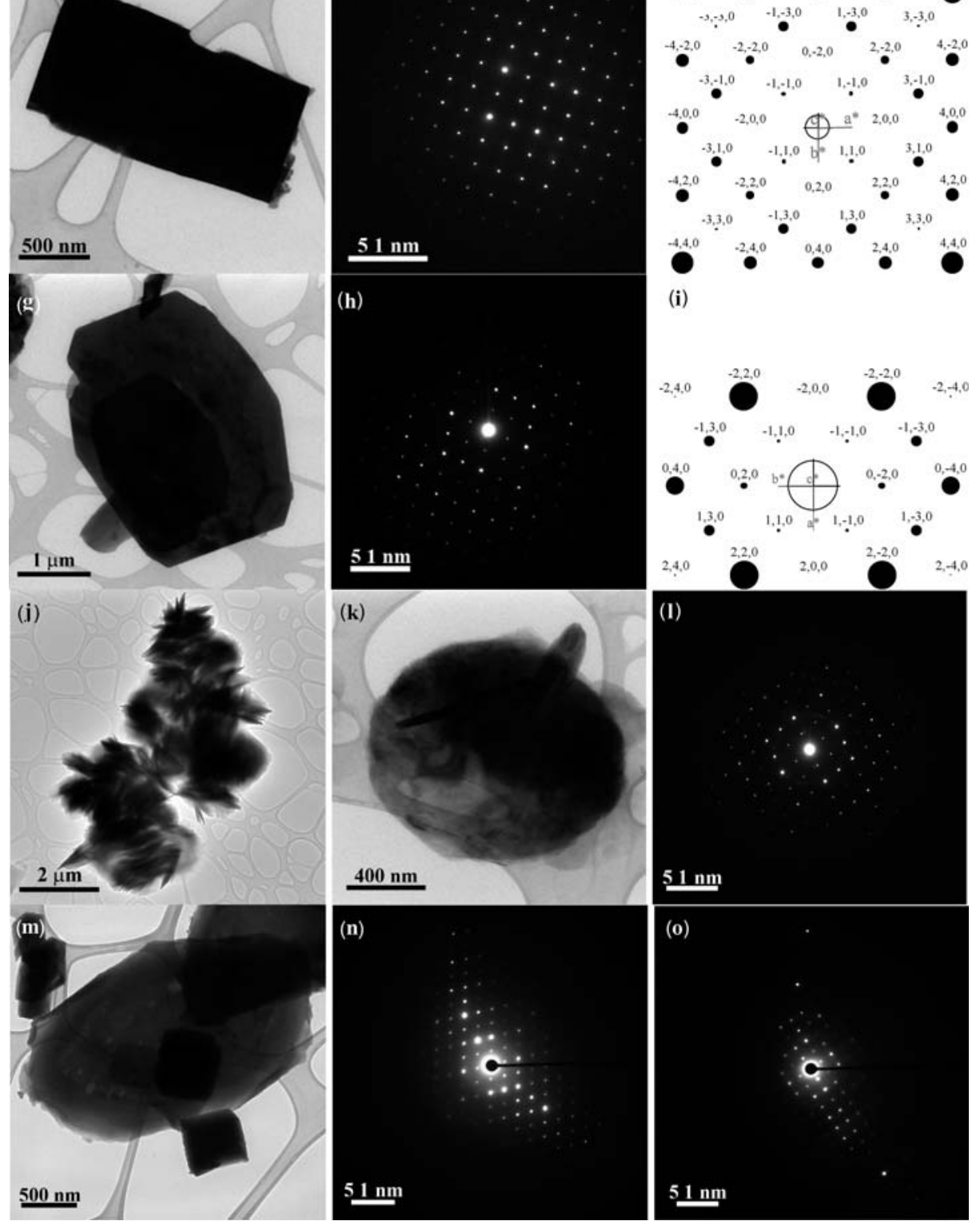

Fig. 5 (a) SEM bright field micrograph, (b) experimental [001] SADP and (c) simulated and indexed [001] $\mathrm{SADP}_{\text {from the octagonal VOPO }} \cdot 2 \mathrm{H}_{2} \mathrm{O}$ platelet. (d) Bright field micrograph, (e) experimental [001] SADP, and (f) simulated and indexed [001] SADP from the $\mathrm{VO}\left(\mathrm{H}_{2} \mathrm{PO}\right)_{2}$ cuboid. (g) Bright field micrograph, (h) experimental [001] SADP, and (i) simulated and indexed [001] SADP from the angular platelet morphology of the VOH$\mathrm{PO}_{4} \cdot 0.5 \mathrm{H}_{2} \mathrm{O}$. (j) Bright field micrograph of the rosette, (k) bright field micrograph of one 'petal' from the rosette, and (1) experimental [001] SADP from the rosette morphology of the $\mathrm{VOHPO}_{4} \cdot 0.5 \mathrm{H}_{2} \mathrm{O} .(\mathrm{m})$ Bright field micrograph of a mixture of angular and blocky morphologies, (n) experimental SADP [001] $\left(\mathrm{VOHPO}_{4} \cdot 0.5 \mathrm{H}_{2} \mathrm{O}\right)$ from the angular platelet in $(\mathrm{m})$, and (o) experimental SADP [001] $\left(\mathrm{VO}\left(\mathrm{H}_{2} \mathrm{PO}_{4}\right)_{2}\right)$ from the blocky crystallite in (m). 
Table 3 Materials prepared by reacting $1.0 \mathrm{~g}$ of $\mathrm{VOPO}_{4} \cdot 2 \mathrm{H}_{2} \mathrm{O}$ with different amounts of 1-butanol and octane

\begin{tabular}{lllcl}
\hline Material & VOPO $_{4} \cdot 2 \mathrm{H}_{2} \mathrm{O} / \mathrm{g}$ & $\mathrm{V}: \mathrm{ROH}^{a}$ & 1-Butanol $/ \mathrm{ml}$ & Octane $/ \mathrm{ml}$ \\
\hline $\mathrm{B} 1-0$ & 1.0 & - & 0 & 175 \\
$\mathrm{~B} 1-5$ & 1.0 & $1: 20$ & 5 & 170 \\
$\mathrm{~B} 1-25$ & 1.0 & $1: 50$ & 25 & 150 \\
$\mathrm{~B} 1-50$ & 1.0 & $1: 100$ & 50 & 125 \\
$\mathrm{~B} 1-75$ & 1.0 & $1: 150$ & 75 & 100 \\
$\mathrm{~B} 1-125$ & 1.0 & $1: 250$ & 125 & 50 \\
$\mathrm{~B} 1-150$ & 1.0 & $1: 300$ & 150 & 25 \\
$\mathrm{~B} 1-160$ & 1.0 & $1: 320$ & 160 & 15 \\
$\mathrm{~B} 1-170$ & 1.0 & $1: 340$ & 170 & 5 \\
$\mathrm{~B} 1-175$ & 1.0 & $1: 350$ & 175 & 0
\end{tabular}

${ }^{a}$ Vanadium to alcohol molar ratio.

Table 4 Materials prepared by reacting $\mathrm{VOPO}_{4} \cdot 2 \mathrm{H}_{2} \mathrm{O}$ with different amounts of 1-butanol and octane keeping the $\mathrm{V}: \mathrm{ROH}$ mole ratio of $1: 50$

\begin{tabular}{lllcl}
\hline Material & $\mathrm{VOPO}_{4} \cdot 2 \mathrm{H}_{2} \mathrm{O} / \mathrm{g}$ & $\mathrm{V}: \mathrm{ROH}^{a}$ & $1-\mathrm{Butanol} / \mathrm{ml}$ & Octane $/ \mathrm{ml}$ \\
\hline $\mathrm{B} 2-15$ & 0.6 & $1: 50$ & 15 & 160 \\
$\mathrm{~B} 2-25$ & 1.0 & $1: 50$ & 25 & 155 \\
$\mathrm{~B} 2-50$ & 2.0 & $1: 50$ & 50 & 125 \\
$\mathrm{~B} 2-75$ & 3.0 & $1: 50$ & 75 & 100 \\
$\mathrm{~B} 2-150$ & 6.0 & $1: 50$ & 150 & 25 \\
$\mathrm{~B} 2-160$ & 6.5 & $1: 50$ & 160 & 15 \\
$\mathrm{~B} 2-170$ & 6.75 & $1: 50$ & 170 & 5 \\
$\mathrm{~B} 2-175$ & 7.0 & $1: 50$ & 175 & 0
\end{tabular}

${ }^{a}$ Vanadium to alcohol molar ratio.

that the composition of the solvent is a much more important parameter in influencing the reaction over the concentration range employed.

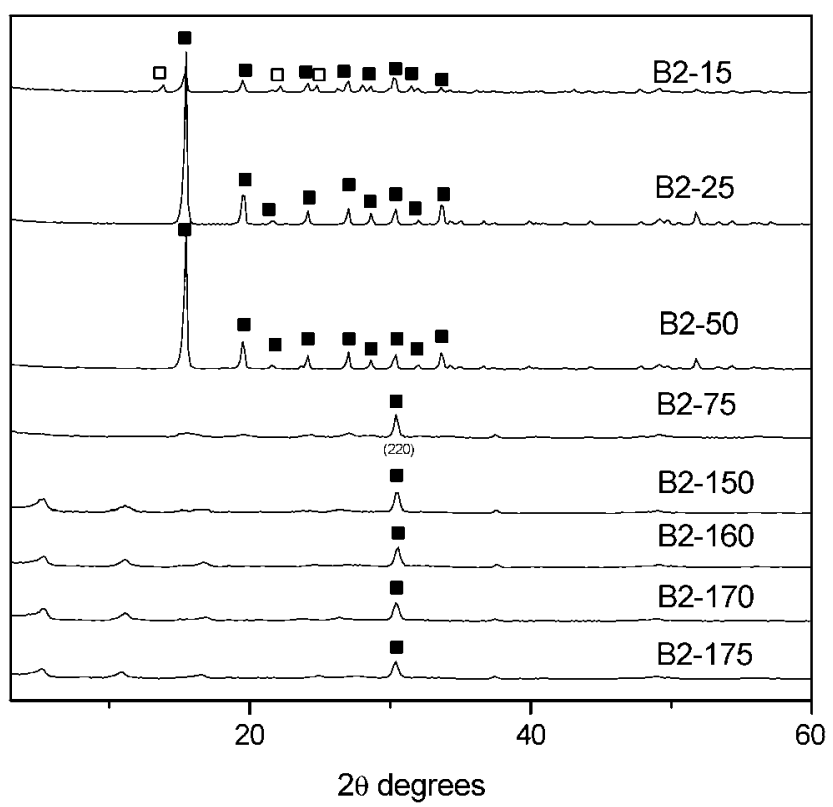

Fig. 6 The XRD patterns of the materials prepared using different amounts of 1-butanol and octane as solvent with a $\mathrm{V}: \mathrm{ROH}$ ratio of 1 : 50. Key: $\mathbf{\square}=\mathrm{VOHPO}_{4} \cdot 0.5 \mathrm{H}_{2} \mathrm{O} ; \square=\mathrm{VO}\left(\mathrm{H}_{2} \mathrm{PO}_{4}\right)_{2}$.

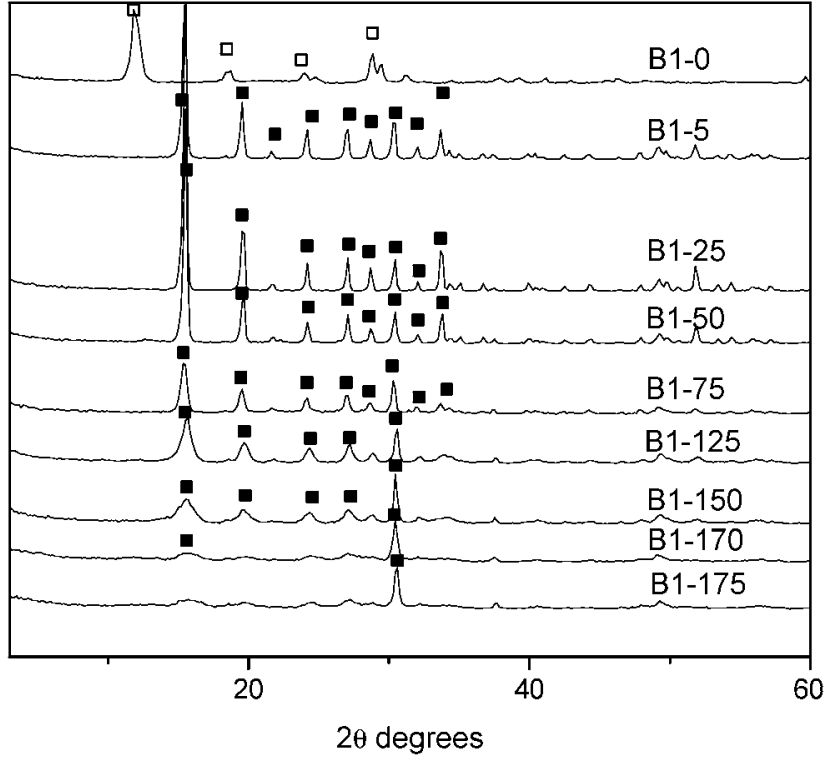

Fig. 7 The XRD patterns of the materials prepared by reacting $1.0 \mathrm{~g}$ of $\mathrm{VOPO}_{4} \cdot 2 \mathrm{H}_{2} \mathrm{O}$ with different amounts of 1-butanol and octane. $\mathrm{Key}: \mathbf{\square}=\mathrm{VOHPO}_{4} \cdot 0.5 \mathrm{H}_{2} \mathrm{O} ; \square=\mathrm{VOPO}_{4} \cdot 2 \mathrm{H}_{2} \mathrm{O}$.

Experiments were also carried out using 1-butanol as the reducing agent with different alkane co-solvents (ESI $\dagger$, Fig. S7$\mathrm{S} 12$ ). With heptane, $\mathrm{VOHPO}_{4} \cdot 0.5 \mathrm{H}_{2} \mathrm{O}$ was the exclusive product for all the solvent mixtures investigated (ESI $\uparrow$, Fig. S7 and S8), whereas with dodecane (ESI $\uparrow$, Fig. S9 and S10) and hexadecane (ESI $\uparrow$, Fig. S11 and S12) $\mathrm{VOHPO}_{4} \cdot 0.5 \mathrm{H}_{2} \mathrm{O}$ was the exclusive product at high 1-butanol concentrations with $\mathrm{VO}\left(\mathrm{H}_{2} \mathrm{PO}_{4}\right)_{2}$ formed at lower alcohol levels. It is interesting to note that as the chain length of the alkane is increased, the amount of alkane that needs to be added to switch the product formed to $\mathrm{VO}\left(\mathrm{H}_{2} \mathrm{PO}_{4}\right)_{2}$ decreases.

The alcohol : alkane volume ratio seems to be a key factor influencing the vanadium phosphate formed. To establish

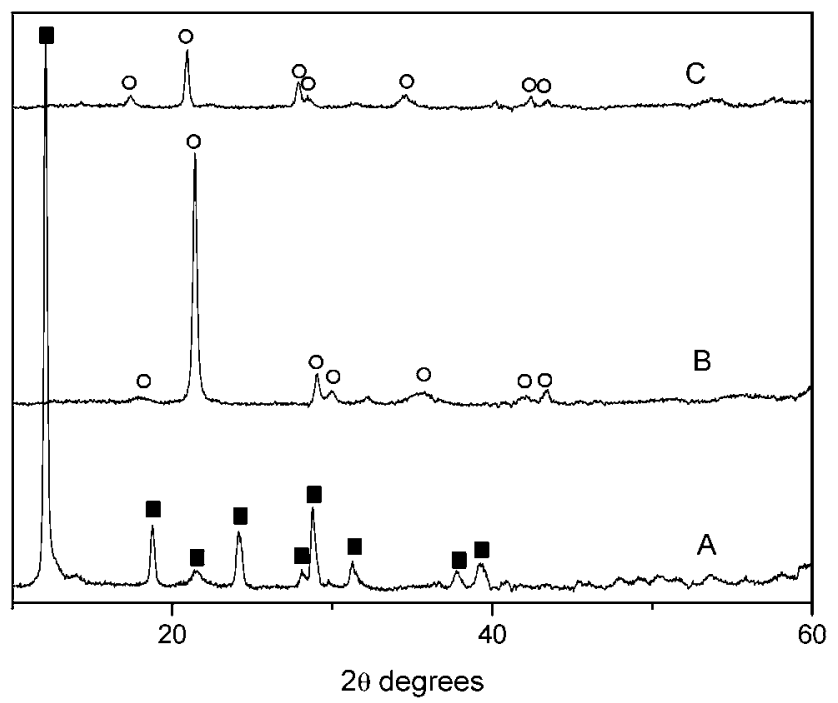

Fig. 8 XRD patterns of $\mathrm{VOPO}_{4} \cdot 2 \mathrm{H}_{2} \mathrm{O}(\mathrm{A})$; after reflux in octane for $24 \mathrm{~h}$ (B) and after reflux in 1-butanol for $24 \mathrm{~h}$ (C). Key: $\boldsymbol{\square}=$ $\mathrm{VOHPO}_{4} \cdot 0.5 \mathrm{H}_{2} \mathrm{O} ; \mathrm{O}=\alpha_{\mathrm{I}}-\mathrm{VOPO}_{4}$. 
whether the alkane is having a chemical effect on the reaction two different possibilities were investigated. The first scenario is that $\mathrm{VOPO}_{4} \cdot 2 \mathrm{H}_{2} \mathrm{O}$ may react with alkane, and is then subsequently reduced with the alcohol. The second possible scenario is that $\mathrm{VOPO}_{4} \cdot 2 \mathrm{H}_{2} \mathrm{O}$ may be initially reduced by the alcohol (1-butanol or 1-octanol) to form $\mathrm{VOHPO}_{4} \cdot 0.5 \mathrm{H}_{2} \mathrm{O}$ and the alkane can then convert the $\mathrm{VOHPO}_{4} \cdot 0.5 \mathrm{H}_{2} \mathrm{O}$ into $\mathrm{VO}\left(\mathrm{H}_{2} \mathrm{PO}_{4}\right)_{2}$.

To investigate the first possibility, $\mathrm{VOPO}_{4} \cdot 2 \mathrm{H}_{2} \mathrm{O}(1 \mathrm{~g}, \mathrm{~A})$ was reacted with octane $(50 \mathrm{ml})$ to form material $(\mathrm{B})$. This was then reacted with 1-butanol $(25 \mathrm{ml})$ to form material $(\mathrm{C})$. From the XRD patterns obtained, material (B) can be assigned to $\alpha_{\mathrm{I}^{-}}$ $\mathrm{VOPO}_{4}$ (Fig. 8) indicating that in the presence of a high boiling point alkane the $\mathrm{VOPO}_{4} \cdot 2 \mathrm{H}_{2} \mathrm{O}$ is dehydrated. However, when this material is then refluxed in 1-butanol for $24 \mathrm{~h}$ no further reaction takes place and the product has a similar XRD pattern to the starting material.

To investigate the second possibility, $\mathrm{VOHPO}_{4} \cdot 0.5 \mathrm{H}_{2} \mathrm{O}$, obtained from the reduction of $\mathrm{VOPO}_{4} \cdot 2 \mathrm{H}_{2} \mathrm{O}$ with 1-butanol, was refluxed in octane for $24 \mathrm{~h}$. As shown in Fig. 9 heating in alkane has no effect on the $\mathrm{VOHPO}_{4} \cdot 0.5 \mathrm{H}_{2} \mathrm{O}$. From these experiments it is clear that the different solvents are not acting individually to influence the reaction and the different products formed must be as a result of the different solvent mixtures. This implies that the different concentration of alcohols obtained by changing the alcohol : alkane volume ratios were the key factor in determining the vanadium phosphate phase formed. If we assume that the $\mathrm{VOHPO}_{4} \cdot 0.5 \mathrm{H}_{2} \mathrm{O}$ and $\mathrm{VO}\left(\mathrm{H}_{2} \mathrm{PO}_{4}\right)_{2}$ are synthesised through two different reaction pathways, any changes in concentration of the alcohol could effect the reaction kinetics of the competing reactions and hence change the selectivity to a particular product.

It has been reported in the literature 3,15 that $\mathrm{VO}\left(\mathrm{H}_{2} \mathrm{PO}_{4}\right)_{2}$ with a V : $\mathrm{P}$ ratio of $1: 2$ can be formed from $\mathrm{VOPO}_{4} \cdot 2 \mathrm{H}_{2} \mathrm{O}$ which has a $\mathrm{V}: \mathrm{P}$ ratio of $1: 1$. This suggests that $\mathrm{VOPO}_{4} \cdot 2 \mathrm{H}_{2} \mathrm{O}$ dissociates in the alcohol to give " $\mathrm{V}^{5+}$ " and " $\mathrm{P}$ " species in the solution as it dissolves at the start of the reaction, which can then subsequently

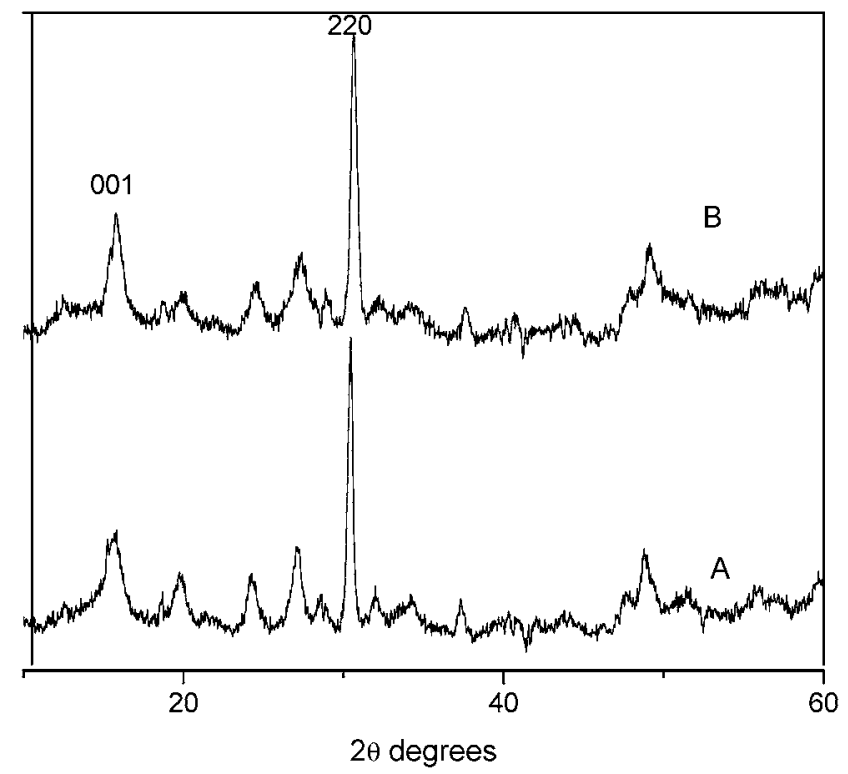

Fig. 9 XRD patterns of $\mathrm{VOHPO}_{4} \cdot 0.5 \mathrm{H}_{2} \mathrm{O}(\mathrm{A})$; after refluxing in octane for $24 \mathrm{~h}(\mathrm{~B})$. react to give the product. To form $\mathrm{VOHPO}_{4} \cdot 0.5 \mathrm{H}_{2} \mathrm{O}$ or $\mathrm{VO}\left(\mathrm{H}_{2} \mathrm{PO}_{4}\right)$ from $\mathrm{VOPO}_{4} \cdot 2 \mathrm{H}_{2} \mathrm{O}$ the $\mathrm{V}^{5+}$ must be reduced to $\mathrm{V}^{4+}$ by the alcohol. It has been shown previously that when $\mathrm{VOH}-$ $\mathrm{PO}_{4} \cdot 0.5 \mathrm{H}_{2} \mathrm{O}$ is formed from $\mathrm{V}_{2} \mathrm{O}_{5}$ and $\mathrm{H}_{3} \mathrm{PO}_{4}$ the initial step is reduction of $\mathrm{V}^{5+}$ to $\mathrm{V}^{4+}$ to give $\mathrm{V}_{4} \mathrm{O}_{9}$ and a $\mathrm{V}^{4+}$ alkoxide. ${ }^{24,25,32} \mathrm{It}$ is also well documented that $\mathrm{VOHPO}_{4} \cdot 0.5 \mathrm{H}_{2} \mathrm{O}$ and $\mathrm{VO}\left(\mathrm{H}_{2} \mathrm{PO}_{4}\right)_{2}$ can be obtained from $\mathrm{V}_{2} \mathrm{O}_{5}$ and $\mathrm{H}_{3} \mathrm{PO}_{4}$ when the $\mathrm{V}$ : $\mathrm{P}$ ratios of the reactants are $1: 1$ and $1: \gg 1$ respectively. ${ }^{28,33,34}$

It was found during this study that $\mathrm{VOHPO}_{4} \cdot 0.5 \mathrm{H}_{2} \mathrm{O}$ was only obtained with a high concentration of alcohol in the solvent mixture. It is proposed that the high concentration of alcohol results in a fast reaction rate between alcohol and $\mathrm{VOPO}_{4} \cdot 2 \mathrm{H}_{2} \mathrm{O}$ and hence a faster reduction rate of $\mathrm{V}^{5+}$ to $\mathrm{V}^{4+}$. Therefore, it is suggested that $\mathrm{VOHPO}_{4} \cdot 0.5 \mathrm{H}_{2} \mathrm{O}$ is obtained when the $\mathrm{V}^{4+}: \mathrm{P}$ ratio was kept at approximately $1: 1$ due to the fast reduction of $\mathrm{V}^{5+}$.

Conversely it was also found that $\mathrm{VO}\left(\mathrm{H}_{2} \mathrm{PO}_{4}\right)_{2}$ was obtained with low concentrations of alcohol in the solvent mixture. The low concentration of alcohol results in a decreased reaction rate (between 1-butanol and $\mathrm{VOPO}_{4} \cdot 2 \mathrm{H}_{2} \mathrm{O}$ ) and a correspondingly slower reduction rate of $\mathrm{V}^{5+}$ to $\mathrm{V}^{4+}$. The slower reduction rate means that the $\mathrm{V}^{4+}$ : $\mathrm{P}$ ratio is $1: \gg 1$ and the excess phosphorus favours the formation of $\mathrm{VO}\left(\mathrm{H}_{2} \mathrm{PO}_{4}\right)_{2}$ which has a $\mathrm{V}: \mathrm{P}$ ratio of $1: 2$.

It can be concluded that the rate of reduction governs whether the $\mathrm{V}^{4+}: \mathrm{P}$ ratio in solution is close to $1: 1$ or $1: \gg 1$ which is the key factor in determining which phase is formed. A scheme of the proposed mechanism of material formation is shown in Fig. 10.

It is well known that when $\mathrm{VOPO}_{4} \cdot 2 \mathrm{H}_{2} \mathrm{O}$ is reduced using an alcohol as both the solvent and reducing agent $\mathrm{VOHPO}_{4} \cdot 0.5 \mathrm{H}_{2} \mathrm{O}$ is formed. ${ }^{1-3}$ However, previous studies have shown that when an aldehyde is used $\mathrm{VO}\left(\mathrm{H}_{2} \mathrm{PO}_{4}\right)_{2}$ is the product. ${ }^{15}$ The alcohol will be oxidised to aldehyde during the reduction of $\mathrm{V}^{5+}$ to $\mathrm{V}^{4+}$ which is a relatively easy reaction, whereas aldehyde will be oxidised to the corresponding carboxylic acid during the reduction which is more difficult. As it is more easily oxidised, the rate of the reduction will be faster when an alcohol is used compared to an aldehyde under same reaction conditions. As the aldehyde is not as effective a reducing agent as the corresponding alcohol, the reduction of $\mathrm{V}^{5+}$ to $\mathrm{V}^{4+}$ will be slower and there will be a $\mathrm{V}^{4+}: \mathrm{P}$ ratio of $1: \gg 1$ favouring the formation of $\mathrm{VO}\left(\mathrm{H}_{2} \mathrm{PO}_{4}\right)_{2}$.

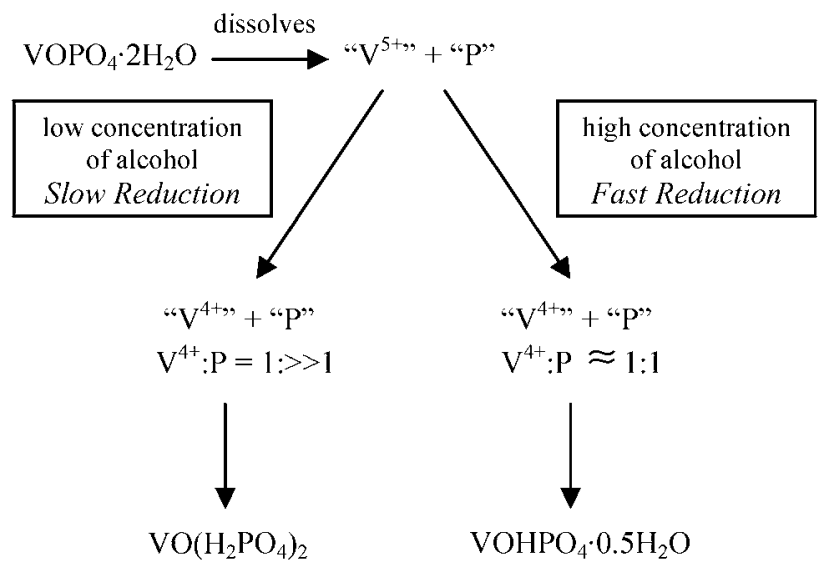

Fig. 10 Proposed mechanism for the formation of $\mathrm{VO}\left(\mathrm{H}_{2} \mathrm{PO}_{4}\right)_{2}$ and $\mathrm{VOHPO}_{4} \cdot 0.5 \mathrm{H}_{2} \mathrm{O}$ from the reduction of $\mathrm{VOPO}_{4} \cdot 2 \mathrm{H}_{2} \mathrm{O}$ with different alcohol/alkane mixtures. 
It is also interesting to consider that $\mathrm{VO}\left(\mathrm{H}_{2} \mathrm{PO}_{4}\right)_{2}$ was the sole product at low concentrations of 1-octanol in octane, but with 1butanol a mixture of $\mathrm{VO}\left(\mathrm{H}_{2} \mathrm{PO}_{4}\right)_{2}$ and $\mathrm{VOHPO}_{4} \cdot 0.5 \mathrm{H}_{2} \mathrm{O}$ was formed when $15 \mathrm{ml}$ of 1-butanol and $160 \mathrm{ml}$ of octane were reacted. As 1-butanol is a better reducing agent than 1-octanol, at low concentrations of 1-butanol the $\mathrm{V}^{4+}$ : $\mathrm{P}$ ratio still seems to be close enough to $1: 1$ to enable formation of $\mathrm{VOHPO}_{4}$. $0.5 \mathrm{H}_{2} \mathrm{O}$, although there are obviously regions of the reaction mixture that favour the formation of $\mathrm{VO}\left(\mathrm{H}_{2} \mathrm{PO}_{4}\right)_{2}$. It seems inevitable that during the standard reduction with alcohol, the reaction mixture will not be a homogeneous mixture and so local regions with $\mathrm{V}^{4+}$ : $\mathrm{P}$ ratios favouring the formation of $\mathrm{VO}\left(\mathrm{H}_{2} \mathrm{PO}_{4}\right)_{2}$ will be present in lesser or greater amounts. Indeed, $\mathrm{VO}\left(\mathrm{H}_{2} \mathrm{PO}_{4}\right)_{2}$ is almost always present as an impurity in $\mathrm{VOHPO}_{4} \cdot 0.5 \mathrm{H}_{2} \mathrm{O}$ and a water reflux step is required to recover pure $\mathrm{VOHPO}_{4} \cdot 0.5 \mathrm{H}_{2} \mathrm{O}$.

\section{Conclusions}

The addition of an $n$-alkane during the alcohol reduction of $\mathrm{VOPO}_{4} \cdot 2 \mathrm{H}_{2} \mathrm{O}$ shows a remarkable influence on the structure of the $\mathrm{V}^{4+}$ vanadium phosphate that is prepared. Here we have shown that the amount of alkane co-solvent added to the reaction can change the product formed. Without alkane the major product is $\mathrm{VOHPO}_{4} \cdot 0.5 \mathrm{H}_{2} \mathrm{O}$ which is the precursor to the industrial catalyst. Addition of the alkane leads to the formation of $\mathrm{VO}\left(\mathrm{H}_{2} \mathrm{PO}_{4}\right)_{2}$, with its characteristic block-shaped crystallites, and the alkane/alcohol liquid phase solubilises the excess vanadium. The amount of alkane required to induce these changes decreased with increasing carbon number of the alkane. Heating both $\mathrm{VOPO}_{4} \cdot 2 \mathrm{H}_{2} \mathrm{O}$ and $\mathrm{VOHPO}_{4} \cdot 0.5 \mathrm{H}_{2} \mathrm{O}$ in alkane resulted in no reaction indicating that the change in morphology is not due to a chemical reaction between the alkane and the vanadium phosphate.

We propose that this is due to the change in reduction rate of $\mathrm{V}^{5+}$ to $\mathrm{V}^{4+}$ which is the key step in our proposed mechanism to determine the product formed (Fig. 10). The results clearly illustrate that the synthesis of heterogeneous catalysts in general, and vanadium phosphates in particular, can be very sensitive to the reaction conditions and that carefully controlled preparation methods are required if unwanted by-products are to be avoided.

\section{Acknowledgements}

We thank the EPSRC for financial support. J.L.N. is indebted to Ministerio de Educación y Ciencia, Spain, for a FPU fellowship. The financial support of the NSF and EPSRC through the Materials World Network program (DMR-Award \#0709887) is also gratefully acknowledged.

\section{Notes and references}

1 J. W. Johnson, D. C. Johnston, A. J. Jacobson and J. F. Brody, J. Am. Chem. Soc., 1984, 106, 8123.

2 H. S. Horowitz, C. M. Blackstone, A. W. Sleight and G. Teufer, Appl. Catal., 1988, 38, 193.

3 I. J. Ellison, G. J. Hutchings, M. T. Sananes and J. C. Volta, J. Chem. Soc., Chem. Commun., 1994, 1093.

4 G. J. Hutchings, A. Desmartin-Chomel, R. Oller and J. C. Volta, Nature, 1994, 368, 41.

5 C. J. Kiely, A. Burrows, G. J. Hutchings, K. E. Bere, J.-C. Volta, A. Tuel and M. Abon, Faraday Discuss., 1996, 105, 103.

6 E. W. Arnold III and S. Sundaresan, Appl. Catal., 1988, 41, 225.

7 K. Ait-Lachgar, M. Abon and J. C. Volta, J. Catal., 1997, 171, 383.

8 F. Benabdelouahab, J. C. Volta and R. Olier, J. Catal., 1994, 148, 334.

9 V. V. Guliants, J. B. Benziger, S. Sundaresan, I. E. Wachs and J. M. Jehng, Chem. Mater., 1995, 7, 1493.

10 V. V. Guliants, J. B. Benziger, S. Sundaresan, I. E. Wachs, J. M. Jehng and J. E. Roberts, Catal. Today, 1996, 28, 275.

11 V. A. Zazhigalov, J. Haber, J. Stoch, L. V. Bogutskaya and I. V. Bacherikova, Stud. Surf. Sci. Catal., 1996, 101, 1039.

12 V. A. Zazhigalov, V. E. Yaremenko and V. G. Il'in, Kinet. Catal., 1999, 40, 128.

13 L. Zeng, H. Jiang and J. Niu, J. Mol. Catal. A: Chem., 2005, 232, 119.

14 E. A. Lombardo, C. A. Sanchez and L. M. Cornaglia, Catal. Today, 1992, 15, 407.

15 J. K. Bartley, C. Rhodes, C. J. Kiely, A. F. Carley and G. J. Hutchings, Phys. Chem. Chem. Phys., 2000, $2,4999$.

16 J. K. Bartley, R. P. K. Wells and G. J. Hutchings, J. Catal., 2000, 195, 423.

17 R. Higgins and G. J. Hutchings, UK Pat., 1601121 (to Imperial Chemical Industries Ltd., UK), 1981.

18 G. J. Hutchings, M. T. Sananes, S. Sajip, C. J. Kiely, A. Burrows, I. J. Ellison and J. C. Volta, Catal. Today, 1997, 33, 161.

19 L. M. Cornaglia, C. A. Sanchez and E. A. Lombardo, Appl. Catal., A, 1993, 95, 117.

20 G. Poli, I. Resta, O. Ruggeri and F. Trifiro, Appl. Catal., 1981, 1, 395.

21 C. Rhodes, G. J. Hutchings, C. J. Kiely and R. Higgins, Abstr. Pap. Am. Chem. Soc., 1999, 217, U683.

22 R. A. Mount and H. O. Raffleson, DE Pat, 2727617 (to Monsanto Co., USA), 1977.

23 T. Shimoda, T. Okuhara and M. Misono, Bull. Chem. Soc. Jpn., 1985, 58, 2163.

24 T. Doi and T. Miyake, Appl. Catal., A, 1997, 164, 141.

25 T. Miyake and T. Doi, Appl. Catal., A, 1995, 131, 43.

26 N. H. Batis, H. Batis, A. Ghorbel, J. C. Vedrine and J. C. Volta, J. Catal., 1991, 128, 248.

27 N. Mizuno, H. Hatayama and M. Misono, Chem. Mater., 1997, 9, 2697.

28 F. K. Hannour, A. Martin, B. Kubias, B. Lucke, E. Bordes and P. Courtine, Catal. Today, 1998, 40, 263.

29 Y. Kamiya, S. Ueki, N. Hiyoshi, N. Yamamoto and T. Okuhara, Catal. Today, 2003, 78, 281.

30 N. Hiyoshi, N. Yamamoto, N. Ryumon, Y. Kamiya and T. Okuhara, J. Catal., 2004, 221, 225.

31 M. T. Sananes, I. J. Ellison, S. Sajip, A. Burrows, C. J. Kiely, J. C. Volta and G. J. Hutchings, J. Chem. Soc., Faraday Trans., 1996, 92, 137.

32 G. J. Hutchings, C. J. Kiely, M. T. Sananes-Schulz, A. Burrows and J. C. Volta, Catal. Today, 1998, 40, 273.

33 M. O'Connor, F. Dason and B. K. Hodnett, Appl. Catal., 1990, 64, 161.

34 F. Cavani, G. Centi and F. Trifiro, Appl. Catal., 1984, 9, 191. 